\title{
The South African Military Nursing College Pupil Enrolled Nurses' experiences of the clinical learning environment
}

\begin{abstract}
Authors:
Ernestina M. Caka ${ }^{1}$

Sebi Lekalakala-Mokgele ${ }^{1}$

Affiliations:

${ }^{1}$ University of Limpopo,

Medunsa Campus,

South Africa

Correspondence to:

Ernestina Caka

Email:

caka@polka.co.za

Postal address:

Private Bag x 72, Medunsa

0204, South Africa

Dates

Received: 11 July 2011

Accepted: 10 Sept. 2012

Published: 06 June 2013

How to site this article

Caka, E.M. \& Lekalakala-

Mokgele, S., 2013, 'The

South African Military

Nursing College Pupil

Enrolled Nurses' experiences

of the clinical learning

environment', Health $S A$

Gesondheid 18(1), Art. \#611,

11 pages. http://dx.doi.

org/10.4102/hsag.v18i1.611

\section{Copyright:}

C 2013. The Authors.

Licensee: AOSIS

OpenJournals. This work

is licensed under the

Creative Commons

Attribution License.

Read online:

The study focused on the clinical learning experiences of Pupil Enrolled Nurses (PENs) within the military health service. The purpose of the research was to explore and describe the learning experiences of PENs within the Military health clinical learning environment. An explorative, descriptive, contextual design which is qualitative in nature was used to guide the study. The military as a training institution prides itself on preparing nurses both as soldiers and nurses, this could be both challenging and exasperating for students, as the scopes are diverse. Being notably very hierarchical, the military's rules constantly take precedence over nursing rules. For the duration of nursing training, students are allocated in the clinical learning area to acquire competencies such as problem solving, cognitive and psychomotor skills (Kuiper \& Pesut 2003:383). Students learn how to merge theory and practice and apply theories in the practical sense. This is however, not done in isolation from the military codes, as they are intertwined. Attendance of military parades and drills are incorporated during this phase. This could create missed opportunities from the clinical learning as students are expected to leave the clinical setting for this purpose. Three focus group sessions were conducted and the experiences of the students, as narrated by themselves, yielded valuable insights. The researcher wrote field notes and assisted with the management of the audio tapes for easy retrieval of information. Data was analysed by the researcher, independent of the cocoder. Two themes relating to the PENs' learning experiences emerged from the data analysed: (1) facilitators of clinical learning, (2) and barriers to clinical learning. The findings obtained depicted those factors which facilitated and obstructed student learning. These findings made it possible for the researcher to make recommendations concerning positive interventions which could be taken to enhance learning.

Die studie het gefokus op die kliniese leerervarings van leerling-ingeskrewe verpleegkundiges (LIV's) in die militêre gesondheidsdiens. Die doel met die navorsing is om die kliniese leerervarings van LIV's binne die militêre gesondheidsomgewing te verken en te beskryf. 'n Verkennende, beskrywende, kontekstuele ontwerp, kwalitatief van aard, is gebruik om die studie te rig. As 'n opleidingsinstituut roem die weermag hulle op die opleiding van verpleegkundiges as soldate, en nie slegs verpleegkundiges nie. Dit kan uitdagend sowel as frustrerend vir studente wees omdat die omvang van hierdie opleiding so divers is. In die weermag, bekend vir sy hiërargie, geniet militêre reëls gedurig voorrang bo verpleegkundige reëls. Vir die duur van die verpleegopleiding word studente aan die kliniese leerareas toegewys om vaardighede soos probleemoplossing en kognitiewe en psigomotoriese vaardighede te bekom (Kuiper \& Pesut 2003:383). Studente leer hoe om teorie en praktyk te verenig en teorie in die praktyk toe te pas. Dit word egter nie geïsoleerd van militêre kodes gedoen nie, aangesien dit alles vervleg is. Bywoning van militêre parades en drilsessies moet in hierdie fase geïnkorporeer word. Dit kan tot verbeurde kliniese opleidingsgeleenthede lei, aangesien daar van studente verwag word om die kliniese omgewing vir hierdie doeleindes te verlaat. Drie fokusgroepsessies is gehou en die ervarings van die studente, soos deur hulleself vertel, het waardevolle insigte gelewer. Die navorser het veldnotas gemaak en was behulpsaam met die hantering van bandopnames om die herroeping van inligting te vergemaklik. Die navorser het die data onafhanklik van die medekodeerder geanaliseer. Twee temas met betrekking tot die leerervarings van LIV's het na afloop van die data-analise aan die lig gekom: (1) fasiliterende faktore vir kliniese leerervaring, (2) struikelblokke tot kliniese leerervaring. Die bevindinge dui op faktore wat die studente se leerervaring fasiliteer, asook struikelblokke tot leerervaring. Na aanleiding van hierdie bevindinge het dit moontlik gemaak vir die navorser om aanbevelings te maak aangaande positiewe intervensies wat toegepas kan word ter bevordering van die leerervaring. 


\section{Introduction}

This study focused on the experiences of military Pupil Enrolled Nurses or students (PENs or students) and specifically the clinical learning environment within the military health service and public health institutions. As an introduction to this study the clinical learning environment, the purpose for allocating the students to this environment as well as the experiences of students in different settings - as found in the literature - are discussed. A limited number of studies have been conducted about the experiences of nursing training within the South African military health service.

\section{Background and rationale}

The clinical learning environment (CLE) has been defined as 'an interactive network of forces influencing studentlearning outcomes in the clinical setting' (Dunn \& Hansford 1997:1299). This environment, according to Carlson (2003:32), gives the students an opportunity to perform skills that are relevant to the needs of their patients. The CLE assists students to be competent in rendering quality nursing care after completion of their training (Dickson, Walker \& Bourgeois 2006:416; Henderson, Forrester \& Heel 2006:275).

The rationale for providing the students with clinical education, which is acquired in the learning area, is to promote the merging of theory and practice (Chan 2002:517; Chesser-Smyth 2005:320; Burns \& Paterson 2005:3). The CLE as a source of exposure to the real world of nursing further develops the students' problem-solving skills, psychomotor skills and cognitive skills (Midley 2006:338). The student nurses embark on a two-year enrolled nursing programme. These are ordinary applicants from all spheres of the country who are trained by the military nursing college and accompanied in the clinical field by military nurse educators. There is a total intake of 20 students per year, amounting to 40 students for both 1st and 2nd year groups. The nursing college allocates students to various clinical environments for clinical experiences as provided for in the regulations of the South African Nursing Council (SANC) and taking into consideration the type of training and the courses followed by the nurses (SANC Regulation 2175, 1993, Par 5).

The aim of this placement of students in the CLE is to afford them the opportunity to practice patient care under the supervision of a qualified clinical nurse in preparation of being able to provide competent care to the patients upon completion of their training (Elliot 2002:69). Many studies have been conducted about the experiences of nurses in the CLE, both positive and negative. Morrison, Boohan, Jenkins and Moutray (2003:94) conducted a study on the placement of students in the clinical learning area and the study yielded positive learning outcomes. Students were encouraged to be part of the team and their learning was supported by the members of the CLE. They were afforded opportunities for learning with a view to developing their competence and expertise. In a study done by Newton, Billet and Ockerby (2009), the challenge faced by students in the CLE was the lack of support they received from both the CLE staff and their facilitators, which led to missed opportunities in terms of teachable moments.

Two main CLEs are utilised by PENs: the military health service and the public health services. In the military health service, only members of the military (various ranks) and their family members may be admitted as patients, whereas the public health sector accommodates patients from all the different spheres of South African society. The CLEs within the military health service comprise only the following units: paediatrics, medical ward, theatre, outpatients, casualty and surgical, with very few patients and with clearly limited areas of specialisation. According to Purdie (2008:315), the students need diversity during clinical placement, ensuring their exposure to a variety of health care experiences and equipping them to nurse holistically. In order to attain this goal in the military health service, students are allocated to public hospitals where there are a variety of learning areas. Lee (2002:119) explains clinical exposure as the placement of students in quality and enriching CLEs, where students will advance on their performance. Edwards, Smith, Courtney, Finlayson and Chapman (2004:248) further explain that the quality of clinical placement not only enhances the competency of students in the performance of skills, but also develops the confidence of the students during the execution of nursing tasks. Hall (2006:627) further reiterates that for a placement to have quality, it needs to have multiple medical and/or nursing disciplines. This is, however, a challenge in the military, since wards are few and students rotate in the same wards over the two year period. In a study by Papp, Markanen and Von Bonsdorff (2003:262), students pointed out that they learned in the CLE by being hands on and the more diverse the placements, the more opportunities they had to excel and be competent. Furthermore, these students highlighted that it is only during placement that they saw patient care being holistic, and this gave them a sense of responsibility. Maginnis and Croxon (2007:218) are of the opinion that clinical placements of students need to be adequate to prepare them to practice in a challenging and ever-changing clinical environment.

Kimberly (2007:369) adds that the inadequacy of clinical experience may lead to students not properly integrating in the workplace after completion of their course. This is further supported by Khoza and Ehlers (2000:50), who state that the purpose of exposing the students to a CLE is for them to acquire skills that will lead them to competency in patient care management.

In the process of improving the quality of student learning, the quality of placements should also be considered to improve exposure and enhance quality learning. Military students could be placed in general practitioners' surgeries, prisons and social services (e.g. hospices) as Clarke (2003:105) recommended. These services could broaden their horizons and present them with a challenge and quality learning climate which could include an environment that 
is supportive, safe and professionally stimulating (Brown, Nolan, Davies \& Keady 2008:1214). Being well prepared and having a positive, quality placement experience can affirm a student's feeling of self worth and give them a sense of belonging.

Contrary to what is expected to be done to enhance clinical exposure, the military nursing college does not place the students at such institutions as they do not have agreements in place with these institutions.

The experiences of students within CLEs have been documented in other settings, particularly with regard to acceptance and being valued by the clinical staff (Hosoda 2006:481; Papp, Markanen \& Von Bonsdorff 2003:263). In other studies conducted by Pearcy and Draper (2008:595), students felt that the wards were more to do with documentation and not necessarily caring. They felt the lack of interpersonal relationships between themselves, the staff members and the patients.

For effective learning to take place, students should feel a sense of belonging. A warm and caring atmosphere must prevail in the CLE.

Students should be welcomed to the group and be part of the team. Levett-Jones and Lathlean (2008:103) define a sense of belonging as 'a deeply personal and contextually mediated experience that evolves in response to the degree to which an individual feels secure, accepted, included, valued and respected by a defined group'.

According to Levett-Jones, Lathlean, Maguire and McMillan (2007:210), Nash, Lemcke and Sacre (2009:48), as well as Hartigan-Rogers, Cobbett, Amirault and Muisee-Davis (2007:1), students need to fit in and be accepted as part of the group during clinical placements, as a workplace environment which is welcoming to students is a source of active participation and provides learning opportunities. Students may present with a low self-esteem and unhappiness, resulting in a diminished learning process upon realising that they are not part of the collective (Baumeister, Twinge \& Nuss 2002:817). There are reports that attest to negative experiences of students in the CLE, indicating the lacking sense of belonging and a feeling of not being welcome (Goh 2003:14; Newton, Billet \& Ockerby 2009).

Mackintosh (2006:953) conducted a study on the socialisation of preregistration student nurses, and was under the impression that professional socialisation should have a positive impact on the students by developing their personality into that of the profession and fostering the caring role of nursing as a profession. However, the findings were contradictory, as students in the CLE were socialised into caring less for the patients in order to cope better with their work situation. According to Cheraghi, Salasi and Ahmadi (2008:14), the purpose of planned clinical experiences is to enable the students to develop interpersonal skills in addition to other skills, and to become accustomed in the norms of the nursing profession.

Nursing in the military health service socialises the students into the norms of the nursing profession, together with the norms of the military ranking system through military training. Prior to admission as student nurses, nurses undergo military training for a period of six months. This period is excluded from their two-year nursing programme. Here they are sensitised to being soldiers first, and nurses second: they receive training by military instructors and not nurses. They are furthermore drilled for physical fitness as part of soldiering and not nursing. Unlike public health nurses, they are trained to observe military laws and legislation and to salute as paying respect to their military seniors, who may not be nurses. Their rank insignia denote that orders are given according to military hierarchical structure and not necessarily nursing ranks. In comparison to their counterparts, student nurses' uniforms resemble those of soldiers. These students face greater challenges, as they have to deal with two demanding professions which differ entirely and have different scopes of practice to master.

Carley and Mackaway-Jones (2005:126) describe nursing as a very hierarchical profession with its roots in the military and religious spheres. The rigid hierarchy of nursing has its power in the hands of its managers, leading to frustration amongst those who occupy the lower ranks in the profession, as their contributions to the profession are constantly belittled (Begley \& Meirs 2004:501). According to LevettJones and Leathlean (2008:342), nurses were socialised into being obedient to authority and not to question any situation, but rather to take orders and acknowledge them as such. They were expected to conform and to comply. This kind of experience amongst the junior members is described by Curtis, Bowen and Reid (2007:156) as horizontal violence in the clinical setting, where students are emotionally harassed - including denial of access to learning opportunities, neglect of clinical practice and intimidation. This leads to poor selfesteem and retarded development. In a study performed by Longo (2007:177), student nurses reported having being verbally and emotionally abused, being put down by higher ranking staff members, humiliated and talked about behind their backs.

This trend is very comprehensible, as students are the lowestranking members in the military health service with a status of Military Skills Development (MSD) and Private, which is a rank in the military given to new members entering the defence force and who face even more challenges within the hierarchy. The uniqueness of the military setting as a CLE for these PENs, prompted the researcher to investigate the experiences of these students, since very little is known about them.

\section{Aims of the study}

This study focused on the experiences of military PENs or students, specifically within the clinical learning environment 
in the military health service and public health institutions. The aim is also to describe the experiences of PEN students in the clinical learning area. As an introduction to this study, the clinical learning environment, the purpose for allocating the students to this environment as well as the experiences of students in different settings, as found in the literature, were discussed. A limited number of studies have been conducted about the experiences of nurses training within the South African military health service.

\section{Problem statement}

The CLE constitutes a clinical setting which offers the students an opportunity to practice the skills necessary to render patient care (Cheraghi et al. 2008:26). This environment serves multiple purposes such as developing competencies amongst students and merging theory and practice (Dickson et al. 2006:416; Midley 2006:338). The experiences of students within a CLE have been documented (Pearcy \& Draper 2008:595). The uniqueness of the military health service CLE means that the experiences of the PENs are different. First, their workplace learning takes place in a military milieu where a hierarchy is at play and where they may have to treat high-ranking personnel as their patients. Secondly, due to the limited number of clinical areas, students are allocated to public hospitals where they attend to patients in their military uniform and are exposed to criticism by the public. This leads to them feeling like they do not belong. Baumeister et al. (2002:817) emphasise that unhappiness can lead to a diminished learning process and low self-esteem amongst students. If the learning process is diminished the researcher has reason to believe that the quality of learning is questionable and the expected delivery of care can be compromised. The researcher's five years of personal experience as an educator in the military health service, and in the light of the reality of the military health service as observed, have placed the researcher in a position to believe that investigation into the experiences of PENs is needed. This has not been done previously and it is not known how these PENs would describe their experiences. Prompted by this problem statement the following research question to PENs arose:

How did you experience the clinical learning environment?

\section{Definition of key concepts}

\section{Clinical Learning Environment}

Dunn and Hansford (1997:1299) describe the CLE as 'an interactive network of forces that aims at influencing the learners' ability to reach their goals in the clinical setting'. The CLE assists the students with the opportunity to acquire the skills and knowledge needed to implement quality nursing care.

The CLE is a recognised learning setting in the form of a hospital or clinic where the students acquire knowledge and skills to manage patients upon completion of their training. It is a setting where they are capacitated to merge theory and practice. There are two formal settings which make use of student nurses: the military health and public health settings.

The military health setting is a formal setting for the development of the skills needed in times of war and defence for the country. PENs are trained in how to care for their patients, i.e. the soldiers who are sick or injured in the line of battle.

\section{Pupil Enrolled Nurses}

The term Pupil Enrolled Nurse (PEN) refers to a person undergoing a two-year programme at an approved nursing school, who has complied with the prescribed conditions and who has furnished the prescribed particulars (Nursing Act 50 of 1978).

\section{Experience}

Experience refers to knowledge or a deep understanding of a situation that has been lived through by a person. A PEN possesses a rich and deep understanding of the CLE that could be clearly related and explained.

\section{Research method and design Design}

A qualitative research approach, which is contextual, was used in this study to explore and describe the learning experiences of the PENs within the military health CLE and public health settings.

\section{Population}

A total of 30 learners constituted the population of this study, which included all PENs enrolled in their second year of training at the military nursing college (Polit \& Beck 2004:50). A total of 19 students voluntarily consented to participate in the study. Purposive sampling was used (Burns \& Grove 2005:352). Only the second-year students formed part of the study as they have been more exposed to placement, both in the military and public health CLE, and faced more challenges. It is only during the second year that students are allocated outside the military sphere.

\section{Sampling criteria}

The eligibility criteria for this study were that participants:

- should be registered as Pupil Enrolled Nurses (PENs) in the Military Nursing College;

- must be in their second year of study; and

- should have been allocated to the military health CLE and the public hospitals.

\section{Data collection methods}

Data was collected by means of the focus group method. Three focus group sessions were conducted, with two groups consisting of six members and a third group consisting of seven members. An experienced moderator was appointed to conduct the interviews. The researcher clarified the 
process of focus group interviews to the participants, as well as the expectations of the moderator during the interviews and how the interviews would be conducted.

The following central question was asked for the purpose of data collection in focus group interviews. How did you experience the clinical learning environment? The interviews emanated from this central question and this allowed for flexibility in the responses.

Data was recorded using a tape recorder, and field notes were handwritten by the researcher. The researcher also assisted in changing tapes and ensuring that all data was well captured.

\section{Data analysis}

Data analysis involves reading through the data repeatedly and engaging in activities of breaking the data down and building it up again in novel ways (Terre'Blanche, Durrhem \& Painter 2007:322). Henning's (2004:126) four steps of data analysis were employed. The researcher commenced with data analysis independent of the cocoder. Audiotapes were labelled before the commencement of the interviews, for accurate retrieval of information. After each interview session, the researcher listened to the tapes and ensured familiarity with their content. All changes in voice tone and pauses were captured. The emotions of the participants were carefully observed during the interviews. Handwritten notes were also taken during the course of the interviews. Subsequent to the interviews, the data from the tapes and from the notes was transcribed. The researcher underlined words and phrases representative of participants' learning experiences of the CLE. The interviews were then typed and read again to check for key words that occurred frequently. Key words were then grouped into categories and were coded to form themes. Data was further reduced into subthemes to construct deeper levels of meaning. These themes and sub-themes were then accurately reported (Henning 2004:127).

Two main themes and 8 sub-themes were identified as either contributing negatively or positively to the CLE:

- facilitators of clinical learning

- barriers to clinical learning.

The researcher engaged an independent cocoder to analyse the data. The cocoder was given unmarked copies of transcribed focus group interviews for her analysis. On conclusion thereof, a telephonic conference was held to discuss the findings and to reach consensus on the analysed transcriptions and field notes. The researcher and the cocoder agreed on the themes and sub-themes. These are found in Table 1 and are supported by the literature and participants' quotations.

\section{Ethical considerations}

The researcher is a lecturer at the Military Health Nursing College and thus presents lectures to the participants. However, the research did not form part of the students'
TABLE 1: Themes and sub-themes identified from the data analysis.

\begin{tabular}{|c|c|c|}
\hline \multirow{2}{*}{$\begin{array}{l}\text { Clinical learning } \\
\text { elements }\end{array}$} & \multicolumn{2}{|c|}{ Type of hospital environment } \\
\hline & Military & Public \\
\hline \multirow[t]{2}{*}{ Facilitators } & $\begin{array}{l}\text { Cognitive learning is } \\
\text { enhanced }\end{array}$ & Quality clinical exposure \\
\hline & $\begin{array}{l}\text { Availability of learning } \\
\text { opportunities }\end{array}$ & $\begin{array}{c}\text { Registered nurses guide } \\
\text { and supervise students' } \\
\text { learning }\end{array}$ \\
\hline \multirow[t]{3}{*}{ Barriers } & $\begin{array}{l}\text { Minimal teaching occurs } \\
\text { in the wards }\end{array}$ & $\begin{array}{l}\text { Deficient sense of } \\
\text { belonging }\end{array}$ \\
\hline & Horizontal violence & - \\
\hline & $\begin{array}{l}\text { Dual role of nurse and } \\
\text { soldier }\end{array}$ & - \\
\hline
\end{tabular}

work and the students were not disadvantaged in any way for not participating in the research. This was clearly stated to them before signing consent for the research and during data collection. A well-skilled moderator conducted the interviews, whilst the researcher assisted in writing field notes and changing the tapes. All information provided by the students was kept confidential. No names were mentioned during the discussions. Numbers were assigned to each student and were stated as such during reporting. Prior consent was given by the participants to divulge, in a manner that cannot be attributed to specific individuals, the information contributed by the participants during the discussions. The students were not exposed to any harmful situation during the course of the study.

\section{Permission to conduct the study}

Data was collected after the following departments had approved the study: the Military Ethics Committee; the ethics committee of the North-West University (Potchefstroom Campus); and the commanding officer of the Military Hospital.

\section{Informed consent}

Informed consent was obtained from the students who wished to participate in the study. A written letter of request was given to the students and a thorough verbal explanation was given with regards to the study.

Students had the right to refuse entering into the study should they choose to do so, and still had the right to withdraw if they did not feel comfortable continuing at any stage. During the research, various principles were followed in order to secure the rights of the participants, particularly in a restrictive environment such as the military. Confidentiality of the information was guaranteed, although complete anonymity would prove difficult due to the nature of data collection which was the focus group discussion method.

The students were selected fairly and without discrimination and purposive sampling was done.

\section{Trustworthiness}

The principles for trustworthiness were applied, as described by Lincoln and Guba (1985). 
TABLE 2: Rigor in research.

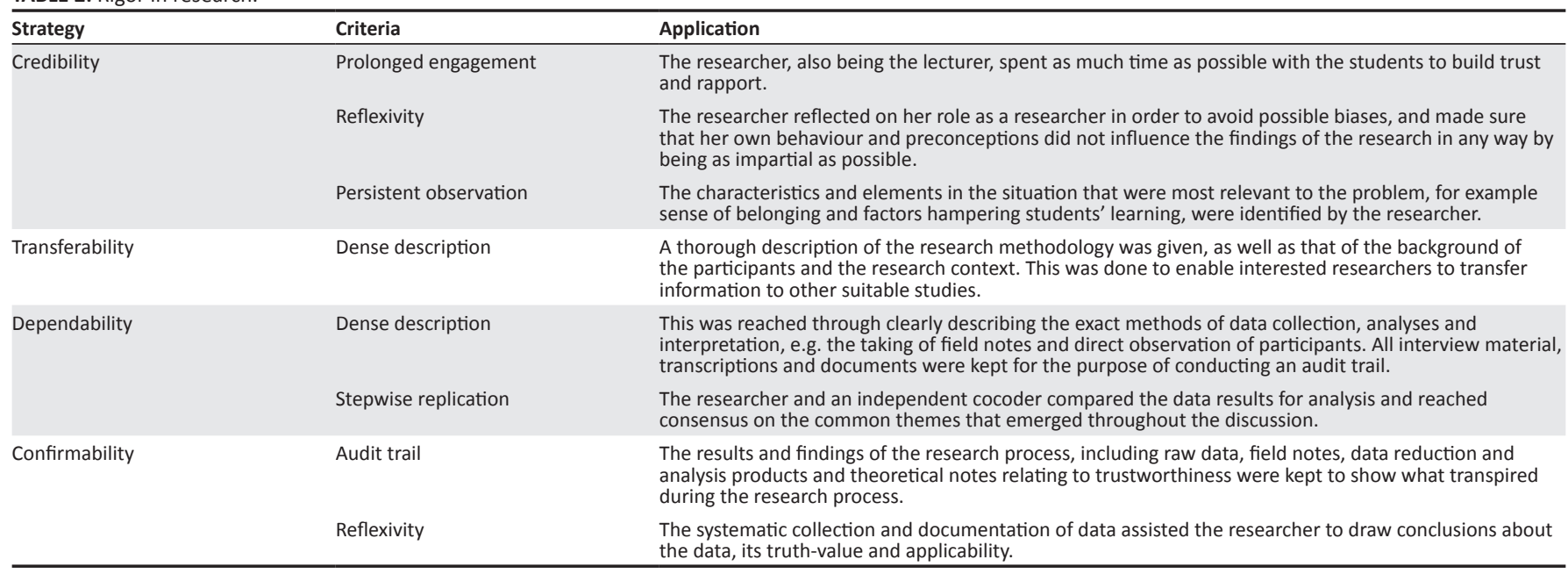

\section{Discussion of results}

\section{Facilitators of clinical learning environment - military hospital environment}

The clinical environment as a learning environment consists of complex and multiple issues that can facilitate or impede student learning. Two sub-themes emerged from the data in this study relating to learning in the military health CLE. These are:

- Cognitive learning is enhanced.

- Availability of learning opportunities.

\section{Cognitive learning is enhanced}

Cognitive learning entails problem solving and taking good decisions on behalf of the patient (Kuiper \& Pesut 2003:383). The students were afforded the opportunity to participate in decision making concerning the patients' treatment.

The participants had this to say:

'They give us the opportunity to find solutions for patients' problems on our own, and to make good judgments.' (Participant 8 , female, aged 20)

\section{Availability of learning opportunities}

The participants admitted to enjoying the learning opportunities provided by the military health setting. They explained how privileged they were to train in a wellresourced institution, with enough equipment and supplies. This provided them with learning opportunities to practice procedures competently. They related their situation as follows:

'In the military health, there are enough supplies for maintaining sterility, unlike in the provincial hospital; here we use sterile gloves and towels for doing a dressing. The provincial hospitals do not have enough supplies for us do the procedures correctly.' (Participant 9, male, PEN)

According to Booyens (2006:266), equipment and supplies are fundamental to enhancing learning for students.
A study conducted by Lita, Alberts, Van Dyk and Small (2002:33) revealed that equipment shortages limit the opportunities for proper teaching and guiding students in the CLE. This is further substantiated by Mongwe (2001:108) who found that equipment shortages in the CLE could have detrimental effects on the learning experiences of the students, as these diminish the effectiveness of the learning climate.

\section{Facilitators of clinical learning - public hospital environment}

Students related different factors as facilitating learning in the CLE in the public hospital environment. Two sub-themes were mentioned, namely:

- quality clinical exposure, as well as

- $\quad$ supervision of students by registered nurses.

\section{Quality clinical exposure}

The public health CLE was deemed beneficial for the students, as it afforded them quality exposure in the form of diverse wards and multiple placements. They related it as such:

'In the provincial hospitals I would say that we are more exposed to what the school is teaching us. They teach us more about what is in the curriculum of the college, for instance they teach us about colostomies.' (Participant 4, male, PEN, aged 23)

According to Lee (2002:119) as well as Levett-Jones (2007:210), clinical exposure means the assignment of students to quality and enriching CLEs, where there is variety of and sufficient CLEs for the students. This affords the students the opportunity to develop their performance and attain skills. Participants in this study expressed their experiences in the following manner:

'We would like to be placed in the public hospitals more often, because we only go there for a short period and we do not get to learn as much as we would like to.' (Participant 18, Female, PEN, aged 23) 
Maginnis and Croxon (2007:218) as well as Gabb and Keating (2005:2) are of the opinion that clinical placements for students need to be adequate and challenging to prepare them for the vast world of nursing. This could be achieved by diversifying the placements to expose students adequately to different settings, consequently maximising the opportunities for learning.

\section{The registered nurses guide and supervise students' learning}

In addition to being afforded diverse clinical placement, students expressed the opinion that they received good guidance and supervision from registered nurses in the wards of the public hospitals - leading to their enjoyment in executing procedures.

This created confidence and competency in implementing nursing procedures, as the supervisor was always around. The above statement was supported as follows:

'When we were working at National at Onco clinic, we the students were the ones going in with the patient ... and the doctor and the doctor will explain everything about the patient, everything, we will do everything under supervision of the doctor.' (Participant 1, female, aged 32)

Clinical supervision is a formal process where the clinical staff accompany and mentor students in achieving competency (Carver, Ashmore \& Clibbens 2007:768). This process seeks to create an environment where students can develop clinical expertise (White \& Roche 2006:209).

The experiences of the student nurses are on par with the findings of Newton, Billet and Ockerby (2009:1) where students expressed gratitude about being supervised and given the opportunity to practice their skills independently.

\section{Barriers to clinical learning - military health environment}

Barriers are obstacles or impediments to the learning process in the clinical situation. The following barriers were identified:

- minimal teaching and lack of supervision occurs in the wards

- horizontal violence

- dual roles.

\section{Minimal teaching occurs in the wards}

Students seem to not have benefited much from the CLE, due to minimal opportunities presented to them in the military health setting with regard to teaching. The following extract demonstrated their frustrations:

'They are not willing to teach us, they want us to do things on our own and when we do them incorrectly it's also wrong.' (Participant 1, female, aged 32)

Burns, Beauchesne, Ryan-Krause and Sawin (2006:172) as well as Croxon and Maginnis (2009:237) assert that clinical education forms a bridge between classroom teaching and practice-based teaching. It provides students with the opportunity to experience the real world of nursing through knowledge acquisition, problem solving and acculturation in the nursing profession

\section{Horizontal violence}

Carley and Mackaway-Jones (2005:126) posit that nursing is a very hierarchical profession, with its roots in the military. It is through this hierarchy that the student nurses experience what is termed as horizontal violence by Curtis, Bowen and Reid (2007:156). This is where junior members in the profession are bullied, ignored and disrespected.

The dilemma of horizontal violence towards students was also identified by Longo (2007:177) to include verbal and/ or emotional abuse. In most cases students will not report the violence to instructors, but rather to their peers. One of the students in this study was physically assaulted by a high-ranking member of the military while carrying out his nursing duties:

'A rank is misused in the military; I was physically assaulted by a high-ranking member while carrying out my nursing duties'. (Participant 4, male, aged 23)

It also occurred that patients were the ones who were giving orders with regard to the care they should receive, particularly to the low-ranking members and students. They get to choose who performs procedures on them and who does not. Students are said to have been deprived of interesting cases where these were related to high-ranking members, as information was concealed from them:

'Sometimes it is more about rank in the military than caring for the patient. You are actually caring for the rank of the person and not the person themselves. You carry out your duties under high scrutiny. You are afraid of making mistakes.' (Participant 4, male, PEN aged 23)

It has been a tradition of nursing to socialise their members into the culture of submission, respect for authority and loyalty to the profession. Nurses become accustomed to doing and saying as they are told, without questioning (Levett-Jones \& Lathlean 2008b:342).

This culture proved to be still at large in the military health setting. In support of identifying this as an issue, the participants had the following to say:

'The patient will tell you that "I am a colonel", they give you orders and you have to act on them.' (Participant 4, male, aged 23)

'There is misuse of military rank ... we can be used like porters and we have to obey.' (Participant 14, male, PEN)

'The patients use their military ranks to treat us badly ... even the wives of the colonels are doing the same.' (Participant 4, male, aged 23)

\section{Dual role of nurse and soldier}

Apart from their profession as nurses, students also undergo military training. The dualism in their role causes a lot of confusion. They narrated this as follows: 
'We are trained as soldiers for war situations and then again as nurses, sometimes we become confused.' (Participant 9, female, aged 23)

'Studying in the military is hard ... we work as students outside, whereas here we are both students and soldiers.' (Participant 10, female, aged 23)

Students can feel confused where they are expected to undertake dual roles, especially the conflicting ones found in this study. This phenomenon was found elsewhere, even though the roles were not of a conflicting nature. For example, in a study conducted by McKenna, Hasson, Keeney and Sinclair (2006:5) on the perceptions of student nurses and perceptions of the role of the health care assistant, students felt the pressure of acquiring dual roles that were incompatible as they were educated to be nurses yet had to undertake the duties associated with being a health care assistant. The dichotomy between the two roles they played led to ambiguity and confusion. The same applies to the participants of this study, as they became confused most of the time between the two contrasting professions and not knowing which one they belonged to.

\section{Deficient sense of belonging; a barrier to clinical learning in the public hospital environment}

The following barrier was identified with regard to the learning of students in the clinical area:

\section{Deficient sense of belonging}

In contrast to the multiple barriers found in the military health setting, participants mentioned only one barrier in the public hospital setting, i.e. being made to feel that they did not belong to the profession. Students in this study explained how they were marginalised and were referred to as soldiers and not as nurses, causing them a lot of embarrassment. The wearing of a military uniform made it easier for them to be blamed for all the wrongs done. Their views were stated as follows:

'Sometimes in public hospitals we feel bad because they will call us soldiers, and sometimes securities. Maybe we are walking around, and the ward is not busy or we are waiting to be given some work, they are sometimes not nice, maybe something was not done, they will say "it's the soldiers", so it's not nice.' (Participant 10, male, aged 24)

For students to socialise into the world of nursing, they need to feel accepted and approved of by the staff members. The clinical environment can be a very hostile environment where clinical staff strongly judge and criticise the students (Levett-Jones \& Lathlean 2008a:104). In studies conducted by Harthon, Matchmes and Tillman (2009:227) as well as Rush, MacCracken and Talley (2009:315), with regard to student nurses' perceptions of the CLE, the experiences of students were very traumatic as they were exposed to harsh remarks and made to feel like outsiders. This was also the case with the students in this study.

'When something is not done is this thing of soldiers, soldiers, it is always a pain for us, they call us soldiers and not nurses. We don't feel like we are part of them.' (Participant 10, male, aged 24)
According to Croxon and Maginnis (2009:236), staff members need to be approachable, available, friendly and willing to teach in order to construct a climate which is conducive to learning. Evidence from empirical data shows that the morale of students can be boosted such that they can be eager to learn if they are welcomed, respected and valued (Chesser-Smyth 2005:320). This was unfortunately not the case with the participants in this study. They felt left out and were furthermore made to feel like strangers.

\section{Limitations of the study}

Although the study provided rich discussions on the experiences of PENs in the CLE, there are some limitations that need mentioning. First, the study only focused on the PENs from one of the three military nursing colleges. The findings of the study could not be generalised to all the military nursing colleges, as these were their unique experiences based on their unique clinical learning experiences. Second, only the experiences of students in their second year of study were explored, and not all the students in the military nursing college.

\section{Recommendations}

In this section, recommendations for nursing education, nursing practice and nursing research will be discussed.

\section{Nursing education}

The findings of this study revealed that for students to learn, they need to be accepted and valued when allocated to the clinical setting. Therefore, the clinical staff should endeavour to create a positive and supportive climate that will enhance learning. According to Nash, Lemcke and Sacre (2009: 49), a supportive CLE provides vital learning opportunities for students in terms of skills, knowledge and practice.

The college should provide the CLE and should clearly outline students' objectives and goals to be met in the first and second year of study within the different wards prior to allocation. This will allow proper alignment with ward allocation, thereby boosting the morale of the students.

A variety of placements could be beneficial to students as this will expose them to different diagnoses and will put them in a position to bring together the world of theory and practice. This is supported by Henderson, Forrester \& Heel (2006:564) who stated that diverse clinical placements provide the students with the opportunity to view nursing in the real world.

However, students need a relatively long time to learn and to become part of the unit. This will improve stability and promote acceptance from unit members, thus allowing learning to take place. Rush, MacCracken and Talley et al. (2009:315) are of the opinion that students need time in the unit to be accepted as part of the group. Unnecessary frequent movements between wards should be avoided. 
Registered nurses should view the teaching of students as one of their integral functions. This will boost the morale of the students. It will also assist students in the successful merging of theory and practice.

Registered nurses should be encouraged by awarding incentives to guide, support and mentor students during their placements, as this will enhance teamwork and motivation levels. Due to resource constraints, peer mentoring could also be ideal, where senior nurses could mentor junior nurses in the wards.

Students should be continuously mentored and supervised in order to gain expertise and confidence in the learning area.

Personnel from both clinical areas, college personnel and the students should undergo regular in-service training and workshops to raise the standards of the institutions relating to new methods and procedures, and create a supportive environment that will benefit the students. This is further reiterated by Li-yu, Yin and $\mathrm{Li}$ (2005:148), in stating that in-service training assists in establishing a supportive atmosphere for staff and creates better interpersonal relationships and work satisfaction. The nursing college could draw up a programme which could include clinical demonstrations for staff members in the hospital to bring them in par with new procedures and developments.

A well-functioning clinical department which could act as a liaison between the college and the hospitals could be a strong recommendation, as the clinical department will also assist with the mentoring of students during clinical placement.

Learner forums could serve as a platform where the students' learning challenges could be voiced and attended to by the relevant committees.

\section{Nursing practice}

Clinical placements should be maximised by considering increased allocation of students to external institutions, as students are only allocated for two months of their twoyear training period to outside institutions. The military hospital lacks diversity and opportunities with regard to the challenge inherent to the number of patients admitted. This is because of the smaller community of military patients, as opposed to the larger numbers of patients in the public health system. This will better the chances of students to gain more knowledge and expertise.

Student participation in clinical care should be recognised and respected by the members of the military health service. It must be recognised that students are in a learning process and need a conducive atmosphere to practice skills and to develop professionally.

Inter-military departmental meetings should be held, where student programmes within the military health service are outlined and explained to different heads of department.
The military step-out uniform (brown skirt or trousers with a white coat depicting the distinguishing student devices which is also used in other military training institutions, could be worn when students are allocated to the public hospitals, so as to enhance their feeling of belonging. LevettJones Levett-Jones and Lathlean (2007:211) cite sense of belonging as a feeling of being accepted and valued, which is what the students need in the clinical area.

A form of identification through the use of distinguishing devices for different levels of students could be of great assistance as the wards will be able to identify the students, thereby meeting their differing objectives through appropriate ward allocation.

\section{Nursing research}

Further studies on the clinical learning experiences of students within the military health service are vital. This study only focused on the PENs in one military health service. Other studies could focus on the other two training campuses in the military health service.

A further study could focus on sense of belonging from a military perspective. This study could focus only on the feeling of belonging for military health students who are allocated to public hospitals.

Studies in the military health service which focus on the diversity of placements for enhancing a smooth transition from PEN to staff nurse might be required to explore whether adequate and diverse placements better equip students to face the challenge of competent nursing care upon completion of their training.

A comparative study on the clinical learning experiences between the military health students and the public health students might perhaps yield a different picture revealing different experiences.

\section{Conclusion}

The findings of this study describe a clearer understanding of the real-life experiences of the student nurses in the military health and public health settings of South Africa. Contrasting experiences between the two CLEs were evident. The students had both facilitating and impeding factors in both the CLEs. Their experiences with regard to clinical learning in the military health service was deemed unsatisfactory, particularly their experiences in relation to horizontal violence, supervision of their learning, learning opportunities and deficient sense of belonging. The public health setting was viewed in a positive light. The participants underwent enriching experiences in the clinical setting which contributed positively to their learning. However, there was one negative experience encountered in the public hospital setting, namely a feeling of alienation and non-acceptance from the team members and patients. This experience caused frustration among the students. 


\section{Acknowledgements}

I would like to thank God, the Almighty, for giving me the strength and courage to complete this study; my husband, Mxolisi Livingstone, for being my pillar of strength throughout this journey; and my two daughters, Rethabile and Ntsiki, for their understanding and patience. Thank you also to my mother, Semakaleng, for her constant support and for looking after my family in my absence - thank you for being my mother. My appreciation go to my brothers, Buti and (the late) Thona, for their mentoring, their belief in me and for being the best brothers anyone could ask for. To my supervisor, Prof Sebi Lekalakala-Mokgele, and cosupervisor, Mrs Gedina De Wet, thank you for your guidance and excellent leadership. To Mrs Vos, whose dedication to her work is amazing: thank you very much for being there when I needed you. To the second-year students, group 15: you were a wonderful group and without you, this study would not have been possible. I also wish to remember the late Mamiki Ntswane-Lebang, for her direction in cocoding, mentoring and shaping the study to what it is today. Finally, I thank the Medical Research Council for believing in me and funding my study.

\section{Competing interests}

The authors declare that they have no financial or personal relationship which may have inappropriately influenced them in writing this article.

\section{References}

Baumeister, R., Twinge, J. \& Nuss, C., 2002, 'Effects of social exclusion on cognitive process: Anticipated aloneness reduces intelligent thought', Journal of Personality and Social Psychology (83) 817-827. http://dx.doi.org/10.1037/0022Personality and
3514.83.4.817

Begley, C. \& Meirs, D., 2004, 'Looking beyond Great Britain', Victims and Victimology (17), 501-510.

Booyens, S.W., 2006, Introduction to Health Services Management, 2nd edn., Juta, Cape Town.

Brown, J., Nolan, M., Davies, S, \& Keady, J., 2008, 'Transforming students' views of gerontological nursing: Realising the potential of "enriched" environments of learning and care', International Journal of Nursing Studies 45(8), 1214-1232. http://dx.doi.org/10.1016/j.ijnurstu.2007.07.002

Burns, C., Beauchesne, M., Ryan-Krause, P. \& Sawin, K., 2006, 'Mastering the Preceptor Role: Challenges of Clinical Teaching', Journal of Paediatric Health Care 20 (3) 172-182. http://dx.doi.org/10.1016/j.pedhc.2005.10.012

Burns, I. \& Paterson, I.M., 2005, Clinical practice and placement support, Supporting learning in practice (5), 3-9.

Burns, N. \& Grove, S.K., 2005, Understanding nursing research, 2nd edn., WB Saunders, Philadelphia.

Carley, S. \& Mackaway-Jones, K., 2005, Major Incident Medical Management and Support: The Practical Approach in the Hospital, Massachusetts, Malden.

Carlson, S., Kotze, W.J. \& Van Rooyen, D., 2003, 'Accompaniment needs of first year nursing students in the clinical learning environment' Curationis 26(2), 30-39. http://dx.doi.org/10.4102/curationis.v26i2.778

Carver, N., Ashmore, R. \& Clibbens, N., 2007, 'Group clinical supervision in preregistration nurse training: The views of mental health nursing students', Nurse Education Today 27, 768-776. http://dx.doi.org/10.1016/j.nedt.2006.10.010

Chan, D., 2002, 'Associations between student learning outcomes from their clinical placement and their perceptions of the social climate of their clinical learning environment', International Journal of Nursing Studies (39), 517-524. http:// environment', International Journal of Nursin
dx.doi.org/10.1016/S0020-7489(01)00057-8

Cheraghi, A., Salasi, M., \& Ahmadi, F., 2008, 'Factors influencing the clinical preparation of BS nursing student interns in Iran', International Journal of Nursing Practice (14), 26-33. http://dx.doi.org/10.1111/j.1440-172X.2007.00664.x

Chesser-Smyth, P., 2005, 'The lived experiences of general student nurses on their firs clinical placement: A phenomenological study', Nurse Education in Practice (5) 320-327. http://dx.doi.org/10.1016/j.nepr.2005.04.001
Clarke, L., 2003, 'Clinical learning environments: An evaluation of an innovative role to support preregistration nursing placements' Learning in Health and Social Care 2(2), 105-115. http://dx.doi.org/10.1046/j.1473-6861.2003.00044.x

Croxon, L. \& Maginnis, C., 2009, 'Evaluation of clinical teaching models for nursing practice', Nurse Education in Practice 9, 236-243. http://dx.doi.org/10.1016/j. nepr.2008.06.004

Curtis, J., Bowen, I. \& Reid, A., 2007, 'You have no credibility: Nursing students' experiences of horizontal violence', Nurse Education in Practice (7), 156-163. http://dx.doi.org/10.1016/j.nepr.2006.06.002

Dickson, C., Walker, J. \& Bourgeois, S., 2006, 'Facilitating undergraduate nurses' clinical practicum: The lived experiences of clinical facilitators', Nurse Education Today (26), 416-422. http://dx.doi.org/10.1016/j.nedt.2005.11.012

Dunn, S. \& Hansford, B., 1997, Undergraduate nursing students' perceptions of their clinical learning environments', Journal of Advanced Nursing (25), 1299-1306. http://dx.doi.org/10.1046/j.1365-2648.1997.19970251299.x

Edwards, H., Smith, S., Courtney, M., Finlayson, K. \& Chapman, H., 2004, The impact of clinical placement location on nursing students' competence and preparedness for practice', Nurse Education Today (24), 248-255. http://dx.doi.org/10.1016/j. nedt.2004.01.003

Elliot, M., 2002, 'Clinical Education: A challenging component of undergraduate nursing education', Contemporary Nurse 12(1), 69-77. http://dx.doi.org/10.5172/ conu.12.1.69

Gabb, R. \& Keating, S., 2005, Work-based learning curricula in nursing, A literature review, Victoria University, Postcompulsory Education Centre.

Goh, K. \& Watt, E., 2003, 'The experience of transition from student to registered nurse in a private hospital graduate program', Australian Journal of Advanced Nursing 20(1), 14-20.

Hall, W.A., 2006, 'Developing clinical placements in times of scarcity', Nurse Education Today (26), 627-633. http://dx.doi.org/10.1016/j.nedt.2006.07.009

Harthon, D., Matchmes, K. \& Tillman, K., 2009, 'The Lived Experience of Nurses Working with Student Nurses in the Clinical Environment', The Qualitative Report $14(2), 227-244$

Hartigan-Rogers, J.A., Cobbett, S.L., Amirault, M.A., \& Muisee-Davis, M.E., 2007, 'Nursing graduates' perceptions of their undergraduate clinical placement', International Journal of Nursing
org/10.2202/1548-923X.1276

Henderson, A.J., Forrester, K. \& Heel, A., 2006, 'The establishment of structures and processes for the safe and effective clinical placement of nursing students', Nurse Education Today (6), 275-280.

Henning, E., 2004, Finding your way in qualitative research, Van Schaik, Pretoria.

Hosoda, Y., 2006, 'Development and testing of a Clinical Learning Environment Diagnostic Inventory for baccalaureate nursing students', Journal of Advanced Nursing 56(5), 480-490. http://dx.doi.org/10.1111/j.1365-2648.2006.04048.x

Khoza, L.B. \& Ehlers, V.J., 2000, 'The competencies of newly qualified psychiatric nurses', Health SA Gesondheid 5(3), 50-59. http://dx.doi.org/10.4102/hsag. v5i3.37

Kimberly, H., 2007, 'Clinical competence among senior nursing students after their preceptorship experience', Journal of Professional Nursing 23(6), 369-375. http:// dx.doi.org/10.1016/j.profnurs.2007.01.019

Kuiper, R.A. \& Pesut, D.J., 2003, 'Promoting cognitive and meta-cognitive reflective reasoning skills in nursing practice', Journal of Advanced Nursing 45(4), 381-391. http://dx.doi.org/10.1046/j.1365-2648.2003.02921.x

Lee, P., 2002, 'Clinical placement exchanges for pre-registration nursing students: Maximising opportunities', Nurse Education in Practice 2, 119-124. http://dx.doi. org/10.1054/nepr.2002.0063

Levett-Jones, T. \& Lathlean, J., 2008a, 'Belongingness: A prerequisite for nursing students' clinical learning', Nurse Education in Practice 8, 103-111. http://dx.doi . org/10.1016/j.nepr.2007.04.003

Levett-Jones, T. \& Lathlean, J., 2008b, 'Don't rock the boat: Nursing students' experiences of conformity and compliance', Nurse Education Today 29(3), 342349. http://dx.doi.org/10.1016/j.nedt.2008.10.009

Levett-Jones, T., Lathlean, J., Maguire, J. \& McMillan, M., 2007, Belongingness: A critique of the concept and implications for nursing education', Nurse Education Today (27), 210-218. http://dx.doi.org/10.1016/j.nedt.2006.05.001

Lincoln, Y.S. \& Guba, E.G., 1985, Naturalistic inquiry, Sage, Beverly Hills.

Lita, H., Alberts, U., Van Dyk, A. \& Small, L.F., 2002, 'Factors that influence the selection of learning opportunities for student nurses in Primary Health Care', Health SA Gesondheid 7(2), 25-79. http://dx.doi.org/10.4102/hsag.v7i2.641

Li-yu, W., Yin, T.J.C., \& Li, I-C., 2005, 'The Effectiveness Empowering In-service Training Programs for Foreign Nurse Aides in Community-Based Long Term Care Facilities', Public Health Nursing 22(9), 147-155. http://dx.doi.org/10.1111/j.0737-1209. Public Health Nur
2005.220208.x

ongo, J., 2007, 'Horizontal Violence Among Nursing Students: Archives of Psychiatric Nursing' 21(3), 177-178. http://dx.doi.org/10.1016/j.apnu.2007.02.005

Macintosh, C., 2006, 'Caring, The socialization of Pre-registration student nurses: A Longitudinal Qualitative Descriptive study', International Journal of Nursing Studies (43), 953-962. http://dx.doi.org/10.1016/j.ijnurstu.2005.11.006

Maginnis, C. \& Croxon, L., 2007, 'Clinical teaching model for nursing practice', Australian Journal of Rural Health 15, 218-219. http://dx.doi.org/10.1111/j.14401584.2007.00888.x 
McKenna, H., Hasson, F., Keeney, S. \& Sinclair, M., 2006, Student Nurses' Experiences and Perceptions of the Role of the Health Care Assistant: Executive Summary, and Perceptions of the Role of the Hea
University of Ulster, Northern Ireland.

Midley, K., 2006, 'Pre-registration student nurses perception of the hospital-learning environment during clinical placements', Nurse Education Today 26(4), 338-345. http://dx.doi.org/10.1016/j.nedt.2005.10.015

Mongwe, R.N., 2001, 'Facilitating learning of student nurses during clinical placement: Registered nurses' perceptions', Unpublished Masters Dissertation, University of South Africa, Pretoria.

Morrison, S., Boohan, M., Jenkins, J. \& Moutray, M., 2003, ‘Facilitating undergraduate interprofessional learning in healthcare: comparing classroom and clinical learning for nursing and medical students', Learning in Health and Social Care 2, 92-104. http://dx.doi.org/10.1046/j.1473-6861.2003.00043.x

Nash, R., Lemcke, P., Sacre, S., 2009, 'Enhancing transition: An enhanced model of clinical placement for final year nursing students, Nurse Education Today (29) 48-56. http://dx.doi.org/10.1016/j.nedt.2008.06.004

Newton, J., Billet, S., Ockerby, M.C., 2009, 'Journeying through clinical placements - An examination of six student cases', Nurse Education Today (Article in Press). http:// dx.doi.org/10.1016/j.nedt.2009.01.009

Nursing Act, 1978, Act 50, South Africa, s.24 ix.

Papp, I., Markanen, M. \& Von Bonsdorff, M., 2003, 'Clinical environment as a learning environment: Student nurses' perceptions concerning clinical learning experiences', Nurse Education Today (23), 262-268. http://dx.doi.org/10.1016/ S0260-6917(02)00185-5
Pearcy, P. \& Draper, P., 2008, 'Exploring clinical learning experiences: Listening to student nurses', Nurse Education Today (28), 595-601. http://dx.doi. org/10.1016/j.nedt.2007.09.007

Polit, D.F. \& Beck, C.T., 2004, Nursing research principles and methods, Lippincott Williams and Wilkins, Philadelphia.

Purdie, A., Sheward, L. \& Gifford, E., 2008, 'Student nurse placements take a new direction', Nurse Education in Practice (8), 315-320. http://dx.doi.org/10.1016/j. nepr.2008.01.001

Rush, K.L., MacCracken, B., \& Talley, C., 2009, 'Nursing students' self-perceptions as insiders in the practice culture', Nurse Education in Practice (9), 314-321. http:// dx.doi.org/10.1016/j.nepr.2008.08.003

SANC: See South African Nursing Council

South African Nursing Council, 1993, Regulations relating to the course leading to enrolment as a nurse, Regulation 2175, Nursing Act 1978(Act no 50 of 1978, as amended) SANC, Pretoria.

South African Nursing Council, Regulation, R254, R2176 and R2175, Course Leading to enrolment as a Nurse.

Terre 'Blanche, M., Durrheim, K. \& Painter, D., 2007, Research in Practice: Applied methods for the Social Sciences, 3rd Impression, Juta, Cape Town.

White, E. \& Roche, M., 2006, 'A selective review of mental health', International Journal of Mental Health Nursing 15(11), 209-219. http://dx.doi.org/10.1111/ j.1447-0349.2006.00424.x 